DOI https://doi.org/10.18551/rjoas.2018-07.34

\title{
BIOACTIVE COMPOUND AND NUTRITIOUS CHARACTERISTIC OF BITTER MELON FRUIT (MOMORDICA CHARANTIA L.)
}

\author{
Rohajatien Ummi* \\ Doctoral Program of Food Technology, Faculty of Agriculture, University of Brawijaya \& \\ Department of Industrial Technology, University of Negeri Malang, Indonesia \\ Harijono, Estiasih Teti \\ Faculty of Food Technology, University of Brawijaya, Indonesia
}

\section{Sriwahyuni Endang}

Faculty of Medicine, University of Brawijaya, Indonesia

*E-mail: ummi.rohajatien.ft@um.ac.id

\begin{abstract}
The bitter melon nutritious profile which was full of nutrition all contributed to flexibility towards curing some kind of diseases. The purpose of the research is to investigate nutritious composition of bitter melon (Momordica charantia L.). The parameter used to detect was as follow: ash content, water content, crude protein, crude fat, total carbohydrate, pectin, dietary fiber, calcium, vitamin $C, \beta$-carotene, diosgenin, stigmasterol, campesterol and $\beta$-sitosterol. The reseach finding showed that the carbohidrate content by different method in the bitter melon was about $60.7-70.90 \%$. The most dominant dietary fiber content was soluble dietary fiber including $19.2-21 \%$ pectin as wel as the most dominant phytochemical coumpound was $\beta$ - sitosterol. Furthermore, crude protein content, crude fat, and ash from fresh bitter melon each was12.8-15.4\%; 0.2-0.4\%; 11.6-13.4\%. Moreover, micro nutritious content such as calcium, vitamin $C$, and $\beta$-carotene each was 676.2-713.4 ppm;119.2126.2ppm and1.5-1.7 ppm. The existance of indigenous components made the bitter melon having high potential as one of the functional food sources.
\end{abstract}

\section{KEY WORDS}

Fresh bitter melon, phytochemical compound, nutrition, functional food.

The bitter melon nutritious profile which is full of nutrient consists of sample and beneficial complex phytochemical compound and all contribute to effective flexibility in curing some kind of disease. The use of bitter melon is not only used as a vegetable in Indonesia, but it is also used traditionally as phlegm emetic, lowering fever and increasing appetite. Bitter melon leaves is utilized as menstruation emetic, burning wound, skin, and worm medicine(Pramono et al., 1998). The utility of bitter melon for southern Japanese society is to cure constipation, laxative and worm disease. Moreover, in India extract bitter melon is used to cure diabetic, rheumatic, liver, and limfa disease (Kumar and Bhowmik, 2010).

The phytochemical compounds in bitter melon are diosgenin and sterol compounds, such as stigmasterol, campesterol and $\beta$-sitosterol. Diosgenin and sterol compound were reported having hypocholesterolamic effect by inhibiting cholesterol absorption and increasing cholesterol secretion (Son et al., 2007). Diosgenin was also reported as biologically active phytochemical that was used to cure some diseases such as leukemia, inflammation, hypercolesrolemia and cancers(Patel and Thompson, 2006). In addition, sterol compounds in bitter melon are sterol crop having similar structure with cholesterol that can inhibitintestinal cholesterol absorption and fat so that they increase bile acid secretion on lumen intestine(Lefebvre et al., 2009).

Bitter melon has been known as vitamin source especially vitamin $C$ as well as mineral, such as calcium, magnesium, iron, zinc, phosphorus, manganese, folic acid, and having high dietary fiber content (Krawinkel and Keding, 2006). Dietary fiber available in bitter melon 
consists of soluble dietary fiber and insoluble dietary fiber. Dietary fiber has an important role to decrease body's weight because of some factors, that is, soluble dietary fiber is fermented in gastro intestine producing two gut hormone, namely, glucagon-like peptide (GLP-1) and peptide $Y Y(P Y Y)$ having effect satietyso that dietary fiber can decrease energy intake significantly(Keenan et al., 2006,Tucker and Thomas, 2009). Second, soluble dietary fiber affects the delay of gastro intestinal emptiness and decrease macronutrient absorption so that it decreases postprandial blood glucose content and insulin(Jenkins et al., 1978).

Besides, the studies of soluble dietary fiber in bitter melon, characteristic of $\beta$-carotene content in bitter melon was also much reported. One of them was the research conducted by Abo et al. 1. They stated that $\beta$-carotene content of bitter melon was doubled compared with broccoli; calcium of bitter melon was doubled higher than spinach, and its total potassium content was doubled higher than banana. The dominant nutritious composition in bitter melon is vitamin $C(570-36444)$ ppm, Calcium $(130-433) \mathrm{ppm}$, diosgenin $(1.69 \mathrm{mg} / \mathrm{gm})$, and protein $(9000-181000)$ ppm. Bitter melon consists of macronutrient such as protein, fat, and carbohydrate as well as micronutrient such as mineral and higher vitamin needed by human body (Ali et al., 2008). In addition, bitter melon (Momordicacharantia, L) is one of food material sources having potential to be developed in functional culinary involving saponin steroid compounds possessing good role to biological activities such as antidiabetic, antihypercholesterolamic, antiobesity, antitumor, antiinflammatory, analgesic and antidepressant (Kumar and Bhowmik, 2010). However, study on nutritious component inside the bitter melon in East Java, Indonesia, is never done yet. By doing so, the research was focused on the nutritious characteristic of fresh bitter melon in Kediri area, East Java, Indonesia. Based on the characteristicresult done, information on comprehensive composition of bitter melon is expected to give accurate information on the content of ash, water, crude protein and fat, total carbohydrate, pectin, calcium, vitamin $C, \beta$-carotene, diosgenin, stigmasterol, campesteroland $\beta$-sitosterol from bitter melon fruit in Kediri area.

\section{MATERIALS AND METHODS OF RESEARCH}

Material of bitter melon was harvested in Kediri residence. Bitter melon fruit from harvesting was moved to Food Industrial Laboratory, Department of Industrial Technology, Engineering Faculty, Universitas Negeri Malang using basket. The other materials used to analyze nutritious component as well as bioactive component analysis of bitter melon were attained from Sigma Chemical Co. and other chemical store in Malang city.

Bitter melon from farmer could be harvested 15 to 20 times every three days. On dry season, the frequency of harvesting was many more if it was supported with good maintenance of plant. The repetition of three times research was done by taking the bitter melon of second, third, and fourth harvesting. Bitter melon picked was packaged with thin plastic and put into fruit basket with maximum two piles that was arranged alternately. To avoid fruit crashing, piece of paper was interspersed between it. Preparation of bitter melon material that would be conducted to analyze nutritious component was done in UniversitasNegeri Malang, Food Industrial Laboratory, Industrial Technology Department, Engineering Faculty. Bitter melon fruit having been harvested from the garden was prepared for the analyses of nutritious composition and bioactive compound involving: 1) ash, 2) protein, 3) fat, 4) total carbohydrate, 5) total sugar, 6) pectin, 7) calcium, 8) vitamin C, 9)diosgenin, 10) stigmasterol, 11) $\beta$-sitosterol, and 12)campesterol, 13) $\beta$-caroten

Nutritious component analysis consisting of water content, ash content, crude protein, crude fat, totalcarbohydrate, Total sugar, $\beta$ - carotene, vitamin $C$ and calcium measurement were done using AOAC method (Horwitz, 1975).

Water content. As much as 1-2-gram sample was put in the flask having been known its weight. Later, the flask and the sample were dried with oven on the temperature of $1050 \mathrm{C}$ for 6 hours until the weight was constant. Next, it was cooled in decicator and weighted. Then,sample was heated in the oven for 30 minutes, cooled, and weighted. Finally, this treatment was repeated until the constant weight was gained. Reduction of material weight is total water content inside the material. 
Ash content. As much as 0.5 -1 gram was weighed in dried porcelain cup that had been known its weight. Next, it was blazed in muffle until it was attained the whitish ash.Cup and ash were put in excicator. After it was cold, it was weighed. Finally, ash content was calculated using formula:

$$
\% \text { ash content }(w b)=\frac{\text { cup weight and ash }(C)-\operatorname{cup} \text { weight }(A)}{\text { sample weight }(B)} \times 100 \%
$$

Crude Protein. Protein content analysis was conducted using microkjeldahl method. First, as much as 0.5-gram sample was put in kjeldahl flask. Second, it was added 1 item kjeldahl tablet and concentrated $20 \mathrm{ml} \mathrm{H} 2 \mathrm{SO}$. Third, it was added 2 boiling stone. Destruction was done for 45 minutes (the clear color sample or green light sample). Next, it was cooled for 10 minutes on room temperature. Distillation process was done by adding 50 $\mathrm{ml}$ aquades into kjeldahl flask that had been cooled. Then, it was added $\mathrm{NaOH} 50 \%$ as much as $70 \mathrm{ml}$ (brown color sample). Kjeldahl flask was installed in distillation tool. Afterwards, Erlenmeyer consisting of $3 \%$ of $\mathrm{H} 3 \mathrm{BO} 3$ as much as $20 \mathrm{ml}$ and addition of 3 drops metilen blue indicator is prepared to keep the yield. Distillation was executed until the resulted distillate achieved $80 \mathrm{ml}$. Distillate was done titration using HCL $0.1 \mathrm{~N}$ until the color changed to purple. Finally, protein content was calculated using formula:

$$
\begin{gathered}
\% \text { Nitrogen }=\frac{(\mathrm{ml} \mathrm{HCl}-\mathrm{ml} \text { blank sample }) \times \mathrm{N} \mathrm{HCl} \times 14 \times 100}{\text { sampleweight }(\mathrm{mg})} \times 100 \% \\
\% \text { Protein }=\% \mathrm{~N} \times \text { conversion factor }(6.25 \text { for fruit })
\end{gathered}
$$

Crude fat. Fat analysis was done using extraction soxhlet method. First, refined dried sample was weighed as much as three grams sand packed with non-fat filter paper. Second, filter paper consisting of sample was put in extraction soxhlet tool. Next, condenser tool was installed above it and fat ash having been known its weight was installed below it. Petroleum ether solvent was put in as needed into fat flask and refluxs was done for 5 hours until solvent that went down into fat flask had clear color. Solvent inside fat flask was distillated and solvent was kept again. Afterwards, fat flask consisting of fat from extracted result was heated on oven with the temperature of $1050 \mathrm{o}$ so that it reached constant weight and it was cooled in excicator. Later, fat flask and its fat were weighed. Finally, fat content can be calculated using formula:

$$
\% \text { fat }=\frac{\text { fat weight }(\mathrm{g}) \times 100}{\text { sample weight }}
$$

Total carbohydrate. Total carbohydrate was measured using by different method calculated using formula:

$$
\% \text { carbohydrate }=100 \%-\%(\text { water }+ \text { ash }+ \text { protein }+ \text { fat })
$$

Total sugar. At first, clear sample solution which was free from impurity was pipette as much as $2 \mathrm{ml}$. Second, it was put in reaction tube and was added $2 \mathrm{ml}$ sulfate copper. Close reaction tube was placed into $100 \mathrm{oC}$ water bath for 10 minutes. Next, it was cooled using flowing water. After it finished, $1 \mathrm{ml}$ arseno molibdat reagent was added and mixed evenly. Reaction tube volume was thinned until the determined volume $(10-25 \mathrm{ml})$ depend on the concentration of solution color. The absorbance value was determined on the wavelength $(\lambda)$ of 500 or $520 \mathrm{~nm}$. The same procedure for blank sample was done by changing sample with aquades. The making of standard curve was done started from concentration of 50, 150 and $300 \mu \mathrm{g} / \mathrm{ml}$ standard glucose solution. The same procedure is used to determine total sugar sample content.

$\beta$-carotene. The $\beta$-carotene content material that will be measured was refined using porcelain crusher. First, the material was weighed as much as $10 \mathrm{~g}$. $\beta$ - carotene inside 
material was extracted using petroleum ether: acetone $(1: 1)$ so that phase ether-carotene was gained. Second, as much as $50 \mathrm{ml}$ sample was washed off for 10 minutes using vortex/magnetic stirrer. Third, sample was filtered and separated using separated funnel. Its residue in the glass was rinsed out with the solvent and its extraction was repeated. Finally, 2 $\mathrm{ml}$ eluate was taken to observe its absorbance value in spectrophotometer with the wave length of $425 \mathrm{~nm}$.

Vitamin C. Vitamin C analysis was done using Adebayo method (Adebayo, 2010). Indophenol's standard solution was prepared by mixing $0.05 \mathrm{~g}$ of 2.6-dichloro Indiphenol added with water until $100 \mathrm{ml}$ and filtered. As standard solution, $0.053 \mathrm{~g}$ vitamin C (ascorbate acid) was dissolved in $90 \mathrm{ml}$ of $20 \%$ metaphosphoric acid and added with water until $100 \mathrm{ml}$. $10 \mathrm{ml}$ of the solution was pipette and put in Erlenmeyer and done titration with indophenol's solution until the color changed into stabile light red for 15 second. Additionally, extracted2 $\mathrm{ml}$ juice from 'calyces' was pipette into Erlenmeyer. $5 \mathrm{ml}$ of $20 \%$ metaphosphor acid (as agent stabilizer) was added and improved until $10 \mathrm{ml}$ volume sign was achieved. Moreover, the result was done titration with indophenol's solution until stabile light color was composed for 15 second. Finally, vitamin C content in 'calyces' was calculated using:

$$
\text { Vit } \mathrm{C} \text { inside } \mu \mathrm{g} / 100 \mathrm{~g}=\frac{\text { titration value } \times 0.212 \times 100}{\text { sample weight }}
$$

$\mathrm{Ca}$ (Calcium). Calcium content was determined using atomic absorption spectrophotometer (AAS) in which dried ashing process of sample was conducted. First, calcium content was determined using percentage or smaller unit measurement (ppm). Ashing process started from weighing ovened porcelain cup which had been identified its weight. Second, $0.5-1$ gram sample was added and heated on temperature of $600 \mathrm{oC}$ until white ash was composed. Third, ash in the cup was taken, cooled and added with concentrated $\mathrm{HC} 1(6 \mathrm{~N})$ of $5 \mathrm{ml}$ and heated in low heating until the result was dry. The heating was done again until it started boiling by adding some what aqueous $\mathrm{HC} 1(3 \mathrm{~N})$ as much as $15 \mathrm{ml}$. The heating to start boiling was repeated again by adding $10 \mathrm{ml}$ of $\mathrm{HCl} 3 \mathrm{~N}$. Afterward, it was cooled and filtered and cup washed with aquades at least three times. Washing water was filtered and filtrate produced was inserted into measurement flask and added with aquades until certain volume. Then, it was filtered and ready to measure its calcium content using atomic absorption spectrofotometer (AAS). Before it was used, AAS tool was set based on manual tool instruction. Later, standard solution, blank sample and sample were measured. During sample determination, standard value was periodically checked whether it was still constant or not. Finally, calcium content could be known from print out produced.

Bioactive Compound Analysis. Bioactive compound analyzed was saponin and steroid compound of cultivar aden bitter melon. The analysis done was diosgenin, stigmasterol, $\beta-$ sitosterol and champesterol compound analysis. Diosgenin, stigmasterol, $\beta$-sitosterol and campesterol content were determined with LC-MS/MS instrument with diosgenin extraction procedure using Chapagain and Wiesman 5 method and sterol compound extraction procedure usedPereira et al. 15.

\section{RESULTS OF STUDY}

Composition of Nutritious Bitter Melon. Bitter melon nutritious component involving water, ash, crude protein and fat, total carbohydrate and $\beta$ - carotene, vitamin $\mathrm{C}$ and calcium on the dry basis were presented in table 1.

Total Carbohydrate $(65.8 \% \pm 5.1 \%)$ was the most dominant component result shown in table 1 , namely total carbohydrate with calculation of by different method of bitter melon of about $60.7 \%$ to $70.9 \%$, with total sugar content was as much as $4.7 \%$ to $7.3 \%$.

Bitter melon phytochemical compound. Phytochemical compound content of bitter melon involving diosgenin, stigmasterol, $\beta$ - sitosterol and campesterol content were presented in figure 1. 
Table 1-Bitter melon nutritious composition

\begin{tabular}{|l|l|l|l|}
\hline No & Nutritious Composition & Content & Unit (dry basis) \\
\hline 1. & Water content & $93.7 \pm 1.7$ & $\%$ \\
\hline 2. & Ash content & $12.5 \pm 0.9$ & $\%$ \\
\hline 3. & Crude protein & $14.1 \pm 1.3$ & $\%$ \\
\hline 4. & Crude fat & $0.3 \pm 0.1$ & $\%$ \\
\hline 5. & Total carbohydrate & $65.8+5.1$ & $\%$ \\
\hline 6. & Pectin & $20.1 \pm 0.9$ & $\%$ \\
\hline 7. & Total sugar & $6.0 \pm 1.3$ & $\%$ \\
\hline 8. & $\beta-$ Carotene & $1.6 \pm 0.1$ & $\mathrm{ppm}$ \\
\hline 9. & Vitamin C & $122.7 \pm 3.5$ & $\mathrm{ppm}$ \\
\hline 10. & Calcium & $676.2 \pm 37.2$ & $\mathrm{ppm}$ \\
\hline
\end{tabular}

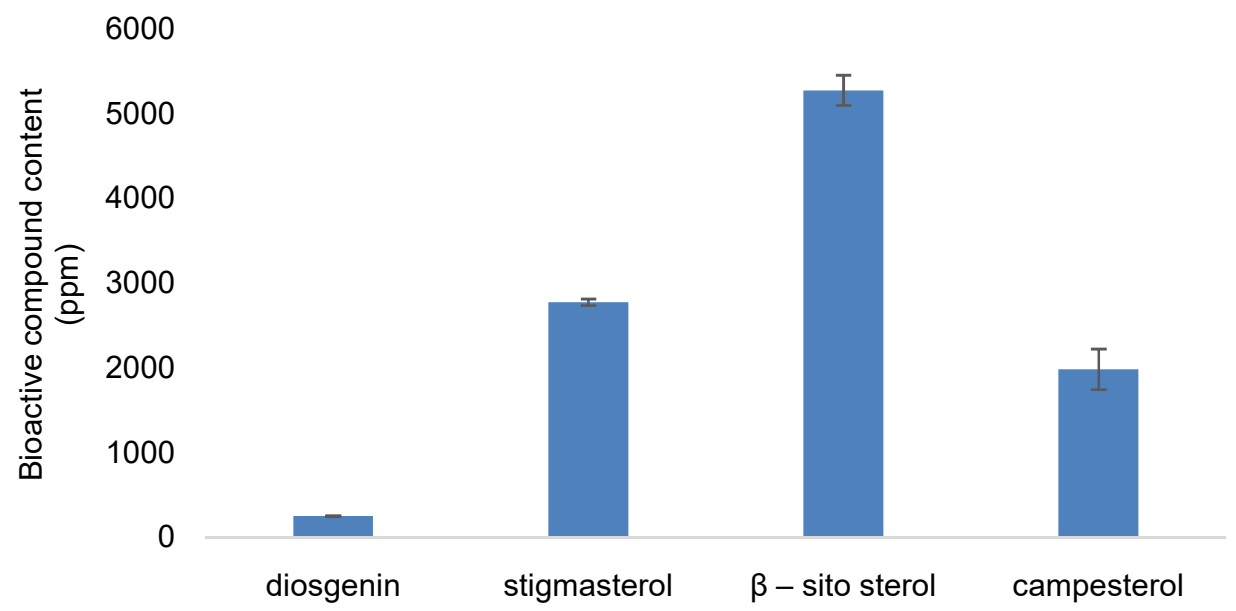

Figure 1-Bitter melon phytochemical compound content

The dominant bitter melon phytochemical compound content presented on figure 1 was $\beta$-sitosterolof about $5275+177.9 \mathrm{ppm}$, followed by stigmasterol, campesterol and diosgenin compound each respectively of about $2774 \pm 38.11 \mathrm{ppm} ; 1982 \pm 239.4 \mathrm{ppm}$; and $249 \pm 5.0$ ppm.

\section{DISCUSSION OF RESULTS}

Bitter melon ash content is $11.6 \%$ to $13.4 \%$. This ash content is approximately to bitter melon's leaves ash content thatis in the group of vegetables $((10.4 \% \pm 0.1 \%)$. It is higher than bitter melon's leaves in the group of young category $(9.4 \% \pm 0.1 \%)$ and it is lower than bitter melon's leaves in the group of yellowing $(22.3 \% \pm 0.2 \%)$. The dominant bitter melon micronutrient's component is calcium with the content of 676.2-713.4 ppm. Together with Vitamin D, calcium is the important micronutrient in maintaining the bone and teeth health. Calcium also has a role to alleviate insomnia, arthritis, menopause, premenstruation syndrome and cramps. The role of calcium in preventing obesity, large intestine cancer, hepatic disease and high hypertension are great possible (Wargovich, 2000). The component of dominant micronutrient of bitter melon respectively was calcium, followed by magnesium and iron with the lower content. Component of bitter melon micronutrient from vitamin category was vitamin $\mathrm{C}$ with the total of 119.2-126.2 ppm and total carotene content of $1.5 \%-1.7 \%$. The two components were vitamin and antioxidant on bitter melon with higher content if compared with other vegetables such as cucumber (Abo et al., 2008).

Bitter melon's macronutrient component consists of protein and fat, each with the content of $12.8 \%$ to $15.4 \%$ and $0.2 \%$ to $0.4 \%$. This protein content is almost the same with crude protein content of bitter melon leaves in vegetable's category $(12.2 \%+0.3 \%)$ which is lower than young bitter melon leaves protein and higher than yellow bitter melon leaves on the research result conducted by Zhang et al. 22. Meanwhile, for the fat content of bitter 
melon in this research result is lower compared with the research conducted. Water content of this vegetable in the research is high enough, that is, $(93.7 \pm 1.7) \%$. The water content value of this fruit was higher than bitter melon's water content in Zhang Min research finding of about $(73.5 \pm 1.2) \%$. The higher water content enables the growth of microorganism causing enzymatic reaction occurred and could alter the component inside (Andress et al., 2006).
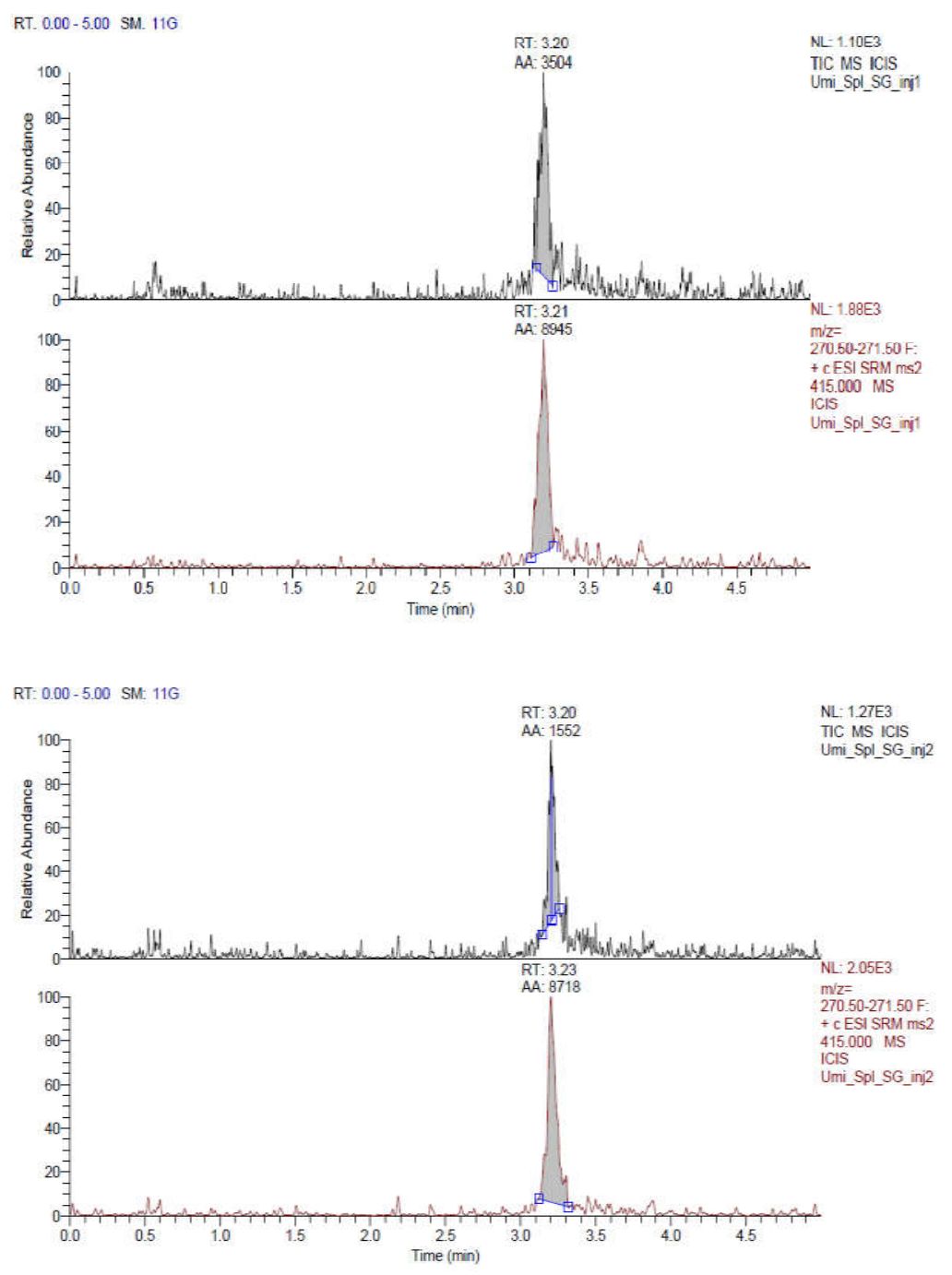

Figure 2-Chromatogram of Diosgenin Compound

Bitter melon diosgenin compound content was $243.8 \mathrm{ppm}$ to $253.8 \mathrm{ppm}$. Diosgenin content of this fruit was higher compared with diosgenin content of this fruit from India, that is, $1690 \mathrm{ppm}$ to $13660 \mathrm{ppm}$. However, in contrary, sterol content, that is, stigmasterol, $\beta$-sito sterol and campesterolof this fruit is still higher than sterol content from India, China, and Thailand. Sterol content of this research respectively each stigmasterol, $\beta$-sitosterol and campesterol started from $2735.8 \mathrm{ppm}$ to $2812 \mathrm{ppm}, 5097.2 \mathrm{ppm}$ to $5453 \mathrm{ppm}$ and 1742.2 $\mathrm{ppm}$ to $2221 \mathrm{ppm}$. The influence of diosgen into glucose content on the normal mice and diabetic mice was reported by Kato et al. (KATO et al., 1995). The research result from Kato et al. stated that PO-1 and PO-2 new hypoglycemic drug presented showed that PO-2 drug had extraordinary hypoglycemic activity on normal mice, whereas PO-1 drug decreased little blood glucose. In addition, PO-1 and PO-2 showed significantly hypoglycemic effect on diabetic mice that is streptozotocin induced. However, steroid glycoside (diosgenin) did not show the influence on the blood glucose level both in induced streptozotocin diabetic mice and in normal mice. Anyhow, in Nualkaew et al. 13 research result stigmasterol showed significant influence $(p<0.05)$ toward the decrease of diabetic mice blood glucose content. 
$\beta$-sitosteroland campesterol have influence toward blood glucose content follow Simonen et al. 17, stating that the absorption decrease from cholesterol and increase compensation from its synthesis directly could affect insulin resistance.
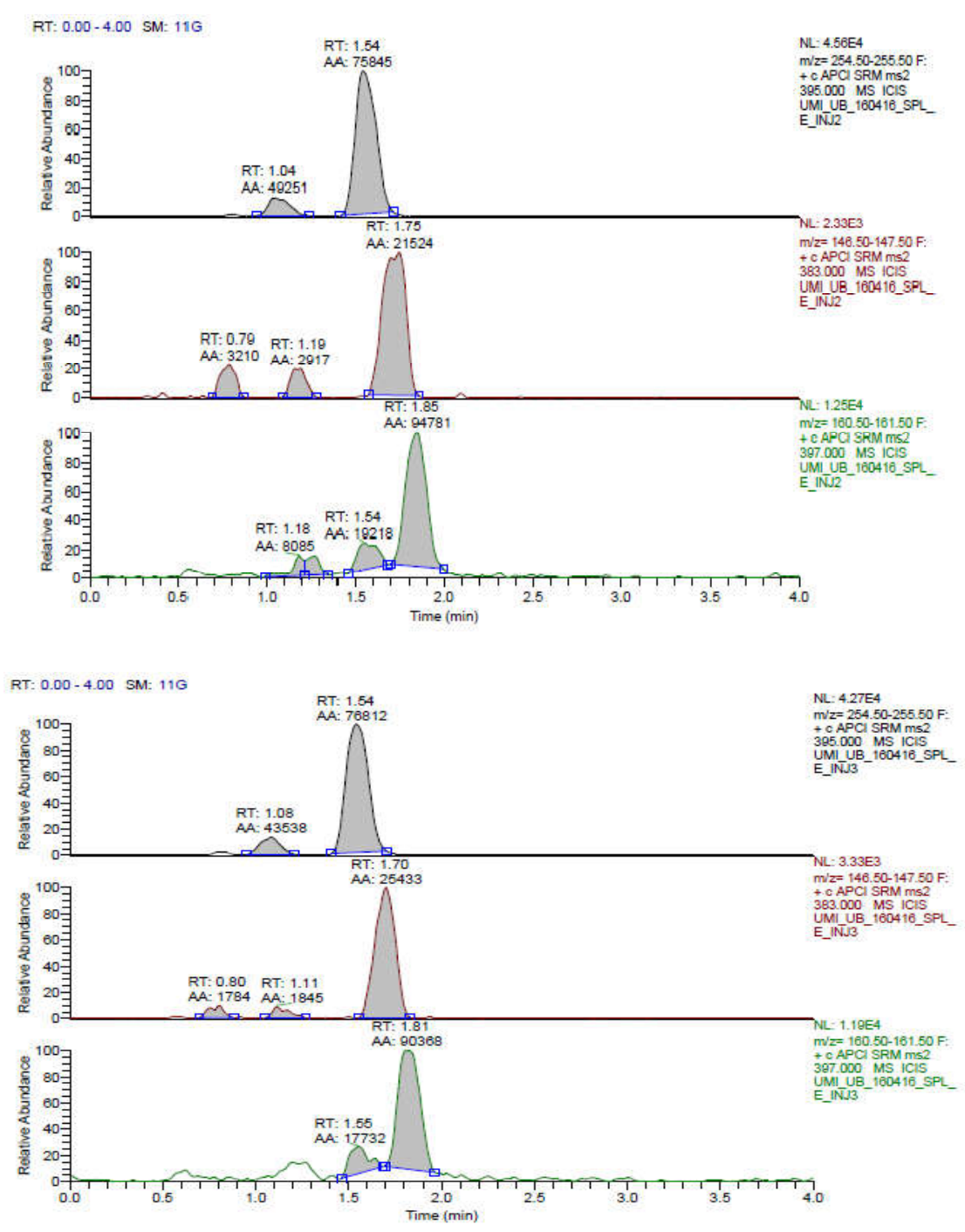

Figure 3-Chromatogram of Sterol Compound

Cholesterol was absorbed through complex mechanism and plant sterol in this case was $\beta$-sitosterol and campesterol that had a role in its process. In practice, plant sterol content, namely, $\beta$-sitosterol and campesterol significantly decreased blood glucose content on diabetic mice. Smahelova et al. 18 research finding showed the significant relationship between insulin sensitivity and glycemic index in increasing cholesterol synthesis and cholesterol absorption decrease.

\section{CONCLUSION}

Phytochemical compounds available in fresh bitter melon in this research were diosgenin in the amount of 243.8-253.8ppm, stigmasterol 2735.8-2812 ppm, campesterol $1742.2-2221 \mathrm{ppm}$ and $\beta$-sitosterol $5097.2-5453 \mathrm{ppm}$. Total carbohydrate by different method was about $60.7-70.9 \%$; crude protein $12.8 \%-15.4 \%$; crude fat $0.2 \%-0.4 \%$; ash content 11.6\%-13.4\%; calcium 676.2-713.4ppm; vitamin C 119.2- $126.2 \mathrm{ppm}$ and total carotene $(1.05-1.85) \%$. Both chemical and phytochemical components of bitter melon that is high enough on the research result revealed its potential as one of functional food sources. 


\section{ACKNOWLEDGMENTS}

We say thank you very much to Directorate General of Research Strengthening and Development, Research Technology and higher Education of Republic of Indonesia Ministry for the grant of this research through Doctor Dissertation Research (PDD) with the contract number: 9.4.2/UN32.14/LT/2015.

All the authors contributed together in conducting and preparing the research and manuscript.

\section{REFERENCES}

1. Abo, K.A., Fred-Jaiyesimi A.A., Jaiyesimi A.E.A. 2008. Ethnobotanical studies of medicinal plants used in the management of diabetes mellitus in South Western Nigeria. Journal of Ethnopharmacology 115(1):67-71.

2. Adebayo, A.O. 2010. Effect of processing methods on chemical and consumer acceptability of kenaf and corchorus vegetables. Journal of American science 6(2):165170.

3. Ali, M.A., Sayeed M.A., Reza M.S., Yeasmin M.S., Khan A.M. 2008. Characteristics of seed oils and nutritional compositions of seeds from different varieties of Momordica charantia Linn. cultivated in Bangladesh. Czech J Food Sci 26(4):275-283.

4. Andress, E.L., Harrison J.A., Reynolds S., Williams P. 2006. So easy to preserve. ed.: Cooperative Extension/The University of Georgia, College of Family and Consumer Sciences, College of Agricultural and Environmental Sciences.

5. Chapagain, B., Wiesman Z. 2005. Variation in diosgenin level in seed kernels among different provenances of Balanites aegyptiaca Del (Zygophyllaceae) and its correlation with oil content. African Journal of Biotechnology 4(11).

6. Horwitz, W. 1975. Official methods of analysis. ed.: Association of Official Analytical Chemists Washington, DC.

7. Jenkins, D.J., Wolever T.M., Leeds A.R., Gassull M.A., Haisman P., Dilawari J., Goff D.V., Metz G.L., Alberti K.G. 1978. Dietary fibres, fibre analogues, and glucose tolerance: importance of viscosity. British Medical Journal 1(6124):1392-1394.

8. KATO, A., MIURA T., FUKUNAGA T. 1995. Effects of steroidal glycosides on blood glucose in normal and diabetic mice. Biological and Pharmaceutical Bulletin 18(1):167168.

9. Keenan, H.A., Doria A., Aiello L.P., King G.L. 2006. Positivity of C-peptide, GADA and IA2 antibodies in type 1 diabetic patients with extreme duration. Diabetes 55:A65.

10. Krawinkel, M.B., Keding G.B. 2006. Bitter gourd (Momordica Charantia): A dietary approach to hyperglycemia. Nutrition reviews 64(7 Pt 1):331-337.

11. Kumar, K.P.S., Bhowmik D. 2010. Traditional medicinal uses and therapeutic benefits of Momordica charantia Linn. International Journal of Pharmaceutical Sciences Review and Research 4(3):23-28.

12. Lefebvre, P., Cariou B., Lien F., Kuipers F., Staels B. 2009. Role of bile acids and bile acid receptors in metabolic regulation. Physiological reviews 89(1):147-191.

13. Nualkaew, S., Padee P., Talubmook C. 2015. Hypoglycemic activity in diabetic rats of stigmasterol and sitosterol-3-O--D-glucopyranoside isolated from Pseuderanthemum palatiferum (Nees) Radlk. leaf extract. Journal of Medicinal Plants Research 9(20):629635.

14. Patel, M.D., Thompson P.D. 2006. Phytosterols and vascular disease. Atherosclerosis 186(1):12-19.

15. Pereira, C.M.P., Nunes C.F.P., Zambotti-Villela L., Streit N.M., Dias D., Pinto E., Gomes C.B., Colepicolo P. 2017. Extraction of sterols in brown macroalgae from Antarctica and their identification by liquid chromatography coupled with tandem mass spectrometry. Journal of Applied Phycology 29(2):751-757.

16. Pramono, S., Ngatijan, Sudarsono S., Budiono, Pujoarianto A. 1998. Obat Tradisional Indonesia I. ed., Yogyakarta: Pusat Penelitian Obat Tradisional UGM. 
17. Simonen, P., Gylling H., Howard A.N., Miettinen T.A. 2000. Introducing a new component of the metabolic syndrome: low cholesterol absorption-. The American journal of clinical nutrition 72(1):82-88.

18. Smahelova, A., Hyspler R., Haas T. 2007. Relation of cholesterol metabolism and noncholesterol sterols to insulin resistance. Physiological research 56(6):749.

19. Son, I.S., Kim J.H., Sohn H.Y., Son K.H., Kim J.S., Kwon C.S. 2007. Antioxidative and hypolipidemic effects of diosgenin, a steroidal saponin of yam (Dioscorea spp.), on highcholesterol fed rats. Bioscience, biotechnology, and biochemistry 71(12):3063-3071.

20. Tucker, L.A., Thomas K.S. 2009. Increasing total fiber intake reduces risk of weight and fat gains in women. The Journal of nutrition 139(3):576-581.

21. Wargovich, M.J. 2000. Anticancer properties of fruits and vegetables. HortScience 35(4):573-575.

22. Zhang, M., Hettiarachchy N.S., Horax R., Chen P., Over K.F. 2009. Effect of maturity stages and drying methods on the retention of selected nutrients and phytochemicals in bitter melon (Momordica charantia) leaf. Journal of food science 74(6):C441-448. 